RJPSS March 2020 Vol. XLV No.1, ISSN: (P)0258-1701 (e)2454-3403 Impact Factor: 7.712

\title{
"Social Problems of Third Gender" A Sociological Study with Special Reference to Chikmagalure District
}

\author{
R.Devananda*, Pushpavathi D.P**, Dr.G.D.Narayana $* * *$ \\ *Research Scholar, **Lect. in Sociology, ***Research Supervisor \\ Deptt. of $R \& D$ in Sociology, \\ Bharathiar University, Coimbatore, Tamilnadu. \\ Email: devanandar59@gmail.com
}

\begin{abstract}
Universally there are Male genders; Female gender and Third gender are in existence. Generally male gender and female gender are well socially recognized by the society in the world. Unfortunately the Third gender is not socially well recognized. The recognization of Third gender defers from country to country in the world.
\end{abstract}

Reference to this paper should be made as follows:

Received: 17.12.2019

Approved: 05.03.2020

R. Devananda, Pushpavathi D.P, Dr. G. D Narayana, "Social Problems of Third Gender" A Sociological Study With Special Reference to Chikmagalure District

Article No. 06

RJPSS March 2020, Vol. XLV No. 1, pp. 047-057

Online available at:

https://anubooks.com/

?page $\mathrm{id}=6389$

https://doi.org/10.31995/

ripss.2020.v45i01.006 
"Social Problems of Third Gender" A Sociological Study With Special Reference to Chikmagalure District

R.Devananda, Pushpavathi D.P, Dr.G.DNarayana

\section{Introduction}

Universally there are Male genders; Female gender and Third gender are in existence. Generally male gender and female gender are well socially recognized by the society in the world. Unfortunately the Third gender is not socially well recognized. The recognization of Third gender defers from country to country in the world.

At the time of Ramayana and Mahabharata also the Third gender was in existence. In India according to Vedic culture recognizes three genders between $500 \mathrm{BC}$ to $1500 \mathrm{BC}$ according to one's nature or prakruthi. These are also spelled out in Kama sutra in 4 th century AD and elsewhere as:

1) Pums-prakrti male in nature,

2) Srti-Prakrti female in nature,

3) Tritiy-prakrti third- nature.

In premodern Indian history Third gender individuals are well known as male-bodied or female-bodied people as well as inter sexual and that can often be recognized from their childhood. A third sex is discussed in ancient Hindu law, medicine, linguistics and astrology. The foundational work of Hindu law, the Manu Smriti (c. 200 BC-200 AD) explains the biological origins of the three sexes:

A male child is produced by a greater quantity of male seed, a female child by the prevalence of the female If both are equal, a third sex child or boy and girl twins are produced $\sim$ if either are weak or deficient in quantity, a failure of conception results.

The two great Sanskrit epic poems, the Ramayana and the Mahabharata indicate the existence of a third gender in ancient Indic society. Some versions of Ramayana tell that in one part of the story, the hero Rama heads into exile in the forest. Halfway there, he discovers that most of the people of his home town Ayodhya were following him. He told them, "Men and women, turn back", and with that, those who were "neither men nor women" did not know what to do, so they stayed there. When Rama returned to from exile years later, he discovered them still there and blessed them, saying that there will be a day when they, too, will have a share in ruling the world.

In foreign countries like Japan the Third gender is known as X-gender. In Nepal the Third gender would be the persons own self-identification. In New Zealand Third gender is known as Indeterminate. In Pakistan Third gender is known as Zenana in Urdu. In Philippines Third gender is known as 'Gay' men are transwomen. In Thailand Third gender is known as Kathoeys are lady boys. In Egypt Third gender is known as Eunuch. 
The Third gender can be called as HIJRAS and can be defined as those individuals can be categorized by themselves or by society as neither man nor women. By biology defect human chromosomal variation and anatomical defect. Gender is male, female or intersex (Third gender).

Statistical information's of Third Gender In Karnataka state there are nearly 10000/ - hijras there, In my study area there are 30 third gender peoples are leaving.

$\begin{array}{llc}\text { S1 No } & \text { Taluk } & \text { No of Third Gender } \\ 1 & \text { Tarikere } & 4 \\ 2 & \text { Kadur } & 6 \\ 3 & \text { Chikmagalure } & 7 \\ 4 & \text { Mudigere } & 4 \\ 5 & \text { NR Pura } & 3 \\ 6 & \text { Koppa } & 3 \\ 7 & \text { Sringere } & 3\end{array}$

\section{Objectives}

- To analyze the social problems of third gender.

\section{Hypothesis}

- The social status of third gender is not satisfactory

- The economic condition of third gender is not satisfactory.

- They are suffering from social security

\section{Statement clarification}

The Third gender can be called as HIJRAS and can be defined as those individuals can be categorized by themselves are by the society as neither man nor women. By biology defect human chromosomal variation and anatomical defect. Gender is male, female or intersex (Third gender).

\section{Methodology}

In this study we have used simple random sampling method on selected 10 respondents. We have used direct interview method for collection of information by respondents. And also used primary and secondary sources to collect the data with social structural developmental prospective.

\section{Sources of Information}

1) Primary Sources: To collect the primary information I used self prepared questionnaire of social structural developmental prospective for interview finally information is collected by 10 respondents. 
"Social Problems of Third Gender" A Sociological Study With Special Reference to Chikmagalure District

R.Devananda, Pushpavathi D.P, Dr.G.DNarayana

2) Secondary sources: We have collected information from articles, journals, library, news papers and websites.

\section{Theoretical prospective}

For the collation of the data we used Structural, Neo Functional and Conflict prospective.

\section{Topographical features of the study:}

Chikkamagalore is a district in the South Indian state of Karnataka. Coffee was first cultivated in India in Chikkamagalore. The mountains in Chikkamagalore which are a part of the Western Ghats are the source of rivers like Tunga and Bhadra. Geographical scope of study area is chikkamagalore dist., .Chikkamagalore dist., will come under the famous western guts area. Chikkamagalore dist., famous for Coffee, tea, Cardamom, Rubber plantation crops. It is also famous for horticulture corps like coconut, Areca nut, Banana, Mango, Sapota and other crops. It is also famous for Paddy, Raghi, Jower and other food crops. It is also famous for commercial crops like chilies, Onion, Potato and other crops.It is also famous for tourism sports like Dattapita, Mullaiyanagiri, Kallatthigiri, Kemmannagundi, Amruthapura temple and so on. Information regarding chikkamagalore dist., as on today.

\section{According to 2011 census}

Geographical location12 54' and 13 53' north latitude, 75 04' and 76 21' East longitude. Temperature is 310C (Max), 140C (Min). Average Rainfall is $1925 \mathrm{~mm}$. Rivers are Tunga, Bhadra, Vedavathi, Yagachi, Hemavati and Netravathi. Area is 7201 sq km. District headquarter is Chikmagalure.

Population are 10,17,283. Density of Population is $158 / \mathrm{km}$. Sex ratio is Female 969 per 1000 male. Literacy rate is $79.25 \%$ (Male $85.41 \%$ and Female $73.16 \%$ ).

\section{DATA ANALYSIS}

The data collected by using all the research methods, and others sources are analyzed by essential statistical techniques by using analysis of data research report. the data was collected on social structural developmental perspective. 
RJPSS March 2020 Vol. XLV No.1, ISSN: (P)0258-1701 (e)2454-3403 Impact Factor: 7.712

TABLE. 1 PERSONAL PROFILE OF THE RESPONDENS

\begin{tabular}{|c|c|c|c|c|c|}
\hline SL NO & \multicolumn{5}{|c|}{ Pers onal profile of the Respondents } \\
\hline \multirow{2}{*}{1} & \multirow{2}{*}{ Age } & $18-28$ & $29-39$ & $40-50$ & $51+$ \\
\hline & & 3 & 2 & 3 & 2 \\
\hline \multirow{2}{*}{3} & \multirow{2}{*}{ Religion } & Hindu & Christian & Muslim & \\
\hline & & 6 & 1 & 3 & \\
\hline \multirow{2}{*}{4} & \multirow{2}{*}{ Caste } & $\mathrm{SC}$ & ST & OBC & \\
\hline & & 1 & 1 & 04 & \\
\hline \multirow[t]{2}{*}{5} & \multirow[t]{2}{*}{ Education } & Illiterates & $\begin{array}{l}\text { Primary } \\
\text { education }\end{array}$ & $\begin{array}{l}\text { Secondary } \\
\text { education }\end{array}$ & $\begin{array}{c}\text { Higher } \\
\text { education }\end{array}$ \\
\hline & & 00 & 4 & 5 & 1 \\
\hline \multirow[t]{2}{*}{6} & \multirow{2}{*}{$\begin{array}{l}\text { Yearly } \\
\text { Income }\end{array}$} & Up to 24,000 & $\begin{array}{l}24,001 \text { to } \\
30,000\end{array}$ & $\begin{array}{l}30,001 \text { to } \\
40,000\end{array}$ & $40,001+$ above \\
\hline & & 4 & 3 & 2 & 1 \\
\hline \multirow{2}{*}{7} & \multirow{2}{*}{ Occupation } & Begging & Sex working & Other & \\
\hline & & 7 & 2 & 1 & \\
\hline \multirow{2}{*}{8} & \multirow{2}{*}{ Family } & Joint & Nuclear & & \\
\hline & & 0 & 10 & & \\
\hline
\end{tabular}

1. Age

I have interviewed three third gender persons aged between 18 to 28 Years. I have interviewed two third gender persons aged between 29 to 39 Years. I have interviewed three third gender persons aged between 40 to 50 Years.I have interviewed two third gender persons aged between 51 Years above.

\section{Religion}

I have interviewed 6 Hindu, 1 Christian, 3 Muslim

\section{Cast}

I have interviewed $1 \mathrm{SC}, 1 \mathrm{ST}, 3 \mathrm{OBC}$ and others 5 third gender persons.

\section{Education}

I have interviewed 4 Primary education, 5 Secondary education, 1 Higher education third gender respondents .

\section{Yearly Income}

4 Respondents yearly income is $24000 /-, 3$ Respondents yearly income is $30000 /-, 2$ Respondents yearly income is 40000/-, 1 Respondents yearly income is above $40000 /-$.

\section{Occupation}

Out of ten respondents 7 respondents occupation is begging (Basthi). 2 respondents are engaged in sex work. 1 respondents are engaged in petty business. 
"Social Problems of Third Gender" A Sociological Study With Special Reference to Chikmagalure District

R.Devananda, Pushpavathi D.P, Dr.G.DNarayana

\section{Family}

All our respondents are leaving in nuclear families.

Table: 02 THEMATIC ANALYSIS OF THE STUDY

\begin{tabular}{|c|l|c|c|}
\hline Sl. No. & Particulars & Y es & No \\
\hline 01 & Problems of Anatomical / biological defects. & 9 & 1 \\
\hline 02 & Feeling of not behaving like others. & 10 & 0 \\
\hline 03 & Guilty feeling or shyness with public & 10 & 0 \\
\hline 04 & Suffering from loneliness leaving home. & 10 & 0 \\
\hline 05 & Suffering from lack of good education & 9 & 1 \\
\hline 06 & Problems of travelling with public & 10 & 0 \\
\hline 07 & Problems of using in public toilets & 10 & 0 \\
\hline 08 & Suffering from not having good occupation & 10 & 0 \\
\hline 09 & Crisis of entry to Third Genders world & 10 & 0 \\
\hline 10 & Problems of Begging (Basthi) & 0 & 10 \\
\hline 11 & Problem of not having the good social status & 10 & 0 \\
\hline 12 & Harassment by rowdies & 1 & 9 \\
\hline 13 & Harassment by police & 1 & 9 \\
\hline 14 & Exploited by senior Trance genders & 9 & 1 \\
\hline 15 & Problems of sex work & 9 & 1 \\
\hline 16 & Problems of STD's & 9 & 1 \\
\hline 17 & Suffering from family feelings & 10 & 0 \\
\hline 18 & $\begin{array}{l}\text { Suffering from always Abusing, blaming and } \\
\text { suspect by society }\end{array}$ & 10 & 0 \\
\hline 19 & Problems of using government facilities & 10 & 0 \\
\hline
\end{tabular}

\section{Problems of Anatomical / biological defects.}

Generally the third genders are generally having anatomical/ biological defect. That is due to the chromosomal variation and anatomical defect. (Medically speaking a male child will born by a greater quantity of male seeds, a female child will born by the greater quantity of female seeds. If male and female seeds are equal. A Third gender child is boy and girl twin children's may take birth.)

\section{Feeling of not behaving like others.}

Usually third gender persons are behaving in a different manner because of their biological nature after the age of 12 and above. They will not behave like boys or girls but they behave in a different manner in the family and society. For that behavior they won't feel sorry. Their behavior is entirely different from other genders. 
RJPSS March 2020 Vol. XLV No.1, ISSN: (P)0258-1701 (e)2454-3403 Impact Factor: 7.712

\section{Guilty feeling or shyness with public.}

Majority of third gender while moving in the public they will suffer from guilty and shyness because the public will see them in a different manner with so many wrong notions. Public will not cordially treat them in public so there feel guilty and shyness when moving in public. Only a few will not feel guilty and shyness because they are mentally strong.

\section{Suffering from loneliness leaving home.}

Majority of third gender at a time leaving from their native home they feel loneliness and they will suffer mentally. Because the native family members will think about social status of the family and other aspects of the family in the society generally. They won't provide love and affection for the third gender

\section{Suffering from lack of good education.}

Usually majority of the third gender people will suffer from lack of education facilities because their classmates will see them in a different manner and abuse them publicly. So they don't want to continue their education which is available in society.

\section{Problems of travelling with public.}

Generally the third gender will face so many problems while travelling in public. The common public will not respect them, co-operate them in travelling. Nobody is ready to sit along with the third gender in all travelling Medias. So third gender people feel they are marginalized in the public while traveling.

\section{Problems of using in public toilets.}

Usually third gender will not be allowed to enter both male and female toilets. Some time third gender will use female toilets. If they enter male toilets there are chances of abuse.

\section{Suffering from not having the good occupation.}

Indian constitution under part no III and Laws made by the Indian parliament and the state legislature the third gender persons having right to decide their selfidentified gender is also upheld in union government of India and state governments of India has directed to grant legal recognition for their gender identity such as male, female or as third gender. The government is not providing sufficient reservations for them in government jobs and as well as in public and private sector fields. So finally third gender people suffer from lack of good occupation in the society. Majority third gender suffer from job opportunity.

\section{Crisis of entry to Third Genders world}

Majority of third gender at the time of puberty (Physical maturity) the third 
"Social Problems of Third Gender" A Sociological Study With Special Reference to Chikmagalure District

R.Devananda, Pushpavathi D.P, Dr.G.DNarayana

gender tendency will emerge for itself. Then the person starts to act in a different manner in the family and the society. The family and the society will not honor their biological feelings, they abuse them then the thirdgender person will try to enter the third gender world. At the time the family and society will not support generally. So the person him/ herself will try to enter the third gender world. At the time the third gender community will well come the new member by conducting operations in a rude manner or in a good manner with the help of doctors, this process is called as Nirvana. And they will perform rituals. So they will face crisis at the time of entering the third gender world.

\section{Problems of Begging}

Usually the third gender main Occupation is begging (basthi) they won't feel any problems at the time of begging. The common public provides basthi.

\section{Problem of not having the good status}

Generally the third gender will not have good social status because of the wrong knowledge about the third gender in the eyes of society. Only a few have some good social status by performing their jobs as CEO's, Principals, Government executive officers and self employed persons.

\section{Harassment by rowdies}

Only few of the third gender is harassed by rowdies in the society. Majority of the third gender will not harassed by rowdies. In recent days the society is slowly recognizing the third gender.

\section{Harassment by police}

Only some of the third gender are harassed by police. Majority of the third gender will not harassed by police. In recent days police also becoming pro society and they will act on humanitarian basis by keeping the laws aside.

\section{Exploited by senior Trance genders}

Majority of the third gender are harassed senior third genders. Because of their seniority in third gender world they will exploit the new third gender member. There is a relationship of Guruma and Chella. Only few of the third gender will not be harassed by the senior third gender. In some cases they will adopt new third gender member as their daughter also.

\section{Problems of sex work}

Majority of third gender has problems in sex work because the other gender persons will misuse them physically and abuse them mentally.

\section{Problems of STD's.(Sexily transmitted diseases)}

Few of the Third gender will suffer from sexily transmitted diseases. Because 
they will conduct unsafe sex with other gender people and they will suffer from illness and they will be converted in to std hubs and it harms the healthy society. Few of the third gender will not suffer from STD's they will conduct somewhat safe sex.

\section{Suffering from family feelings}

Majority of third gender will suffer from family feelings. Because earlier they are members of the joint family. When the enter the third gender world in the beginning they will suffer a lot by loneliness. Only a few of the third gender will not suffer from family feelings because family members will support them mentally.

\section{Suffering from always abusing, blaming and suspect by society}

Majority of the third gender is suffering from abusing, blaming and suspect by society in general because of their bodily activities. Only a few will not suffer from abusing, blaming and suspect by society. Slowly the tolerance of the society towards third gender is improving day by day.

\section{Not aware and using of government facilities}

Majority of the third genders are unaware of government facilities so they are not able to utilize the government facilities. Only a few of the third gender aware of government facilities and they are utilizing the government facilities

\section{Findings}

a) Third gender people are not treating well in the society by common people.

b) Third gender people have no social status in the society.

c) Third gender people have no economic security in the society.

d) Third gender people are suffering from health problems.

e) Third gender people are marginalized in the society.

\section{Provement of Hypotheses}

By above all studies and statics we can prove the socio economic condition of Third gender is not good.

\section{Suggestions}

\section{Feeling of not behaving like others.}

For above problem of third gender proper counseling should be conducted by the competent persons continuously in taluk levels, district level and state level centers by NGO's, government institutions and others.

\section{Guilty feeling or shyness with public}

For the above problem of third gender they should be educated, family and society should provide love and affection in the early stages itself. 
"Social Problems of Third Gender" A Sociological Study With Special Reference to Chikmagalure District

R.Devananda, Pushpavathi D.P, Dr.G.DNarayana

\section{Problems of travelling with public}

For travelling in public the private, public transport system should provide separate seat reservation as reserved for ladies. Senior citizens like.

\section{Problems of using in public toilets}

For toilet problems separate toilets for male, female, handicapped in such a manner separate toilets should be provided in all public places.

\section{Suffering from good education}

For third gender the society and the government should provide free and compulsory education and reservation in higher education also. The government should start new programs for third gender educational welfare programs.

\section{Suffering from not had the good occupation/ Problems of Begging/ Problems of sex work}

For the above said problem government should provide Reservation in Government and private sector appointments, training to start small scale industries, loan facilities, subsidies and marketing facilities should be provided by government.

\section{Problem of not having the good status}

For the above said problem the third gender should be counseled by the social leaders and society also change their way of thinking to words third gender in 21 century.

\section{Harassment by rowdies, police and senior Third Genders}

For the above said problem legal protection should be provided by the government for third gender by taking needy actions by the government authorities. And new guidelines should be provided by the government for common people and for government agencies.

\section{Problems of STD's}

For the above said problem the society and government should advice Precautionary methods and should provide health facilities for third gender in the interest of the society health.

\section{Suffering from family feelings}

The Society, NGO's and the government should provide Counseling Facilities to Third Genders and their old families. It will help in boosting their morale in the society.

\section{Suffering from always abusing, blaming and suspect by society}

For third gender people we should provideinformation, Motivation to develop their self confidence to face these problems in third Genders and create the awareness 
RJPSS March 2020 Vol. XLV No.1, ISSN: (P)0258-1701 (e)2454-3403 Impact Factor: 7.712

to public to treat third gender as human beings like us.

\section{Not aware of government facilities}

For the above said problem the government should provide all facilities according to the constitution of India. Governmentshould provide ID cards, BPL cards and pensions etc.

\section{Confirmation of Hypothesis}

- By above all studies the social status of third gender is not satisfactory.

- By above all information the economic condition of third gender are not up to the mark.

- The third gender people are suffering from sense of social security.

\section{Conclusion}

Third gender people should be recognized as other genders socially, politically, economically. New humanitarian concept and feelings should arise in society to treat them as our own with belongingness in the interest of the welfare state concept of the Indian constitution.

\section{References}

1. Mazumdar Ajay BasuNiloy, 1997, BharatarHijrahSamaj- Dip Prokashon, Kolkatta.West Bengal.

2. Reddy NcwayanaKS , 2002, The Essentials Of Forensic Medicine And Toxicology: Narayan Gudu, Hydrabad 7. 